\title{
THE ROLE OF PARAVERTEBRAL BLOCKS IN AMBULATORY SURGERY: REVIEW OF THE LITERATURE
}

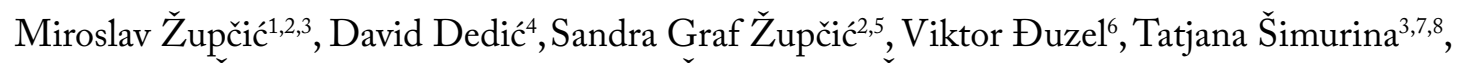
Livija Šakić ${ }^{9}$, Igor Grubješić ${ }^{1}$, Ingrid Šutić ${ }^{2}$, Ivana Sutić ${ }^{10}$ and Andjelko Korušićci,4

${ }^{1}$ Clinical Hospital Centre Rijeka, Clinic of Anesthesiology and Intensive Care Medicine, Rijeka, Croatia; ${ }^{2}$ University of Rijeka, Faculty of Medicine, Department of Physiology and Immunology, Rijeka, Croatia;

3J. J. Strossmayer University, Faculty of Medicine, Osijek, Croatia;

${ }^{4}$ Clinical Hospital Dubrava, Clinic of Anaesthesiology, Reanimatology and Intensive Care Medicine,

Zagreb, Croatia; ${ }^{5}$ Clinical Hospital Centre Rijeka, Clinic of Neurology, Rijeka, Croatia;

${ }^{6}$ Barking, Havering and Redbridge University Hospitals NHS Trust, Department of Anaesthesia, London, United Kingdom; ${ }^{7}$ General Hospital Zadar, Department of Anesthesiology and Intensive Care Medicine,

Zadar, Croatia; ${ }^{8}$ Department of Health Studies University of Zadar, Zadar,Croatia;

${ }^{9}$ Department of Anaesthesiology, Reanimatology and Intensive Medicine, University Hospital "Sveti Duh", Zagreb, Croatia; ${ }^{10}$ University of Rijeka, Faculty of Medicine, Department of Family medicine, Rijeka, Croatia

SUMMARY - Ambulatory surgery often involves surgical procedures on the thorax, abdomen and limbs, which can be associated with substantial postoperative pain. The aim of this narrative review is to provide an analysis of the effectiveness of paravertebral block (PVB) alone or in combination with general anaesthesia, in this setting, with an emphasis on satisfactory postoperative analgesia in comparison to other modalities. We have conducted a search of current medical literature written in English through PubMed, Google Scholar and Ovid Medline ${ }^{\circledR}$. Peer-reviewed professional articles, review articles, retrospective and prospective studies, case reports and case series were systematically searched for during the time period between November 2003 and February 2019. The literature used for the purpose of creating this review showed that utilisation of paravertebral block either alone or in combination with general anaesthesia, has a positive effect on satisfactory analgesia in ambulatory surgery. With a multimodal analgesic approach of PVB and other techniques of anaesthesia and analgesia there is a reduction in postoperative opioid consumption, fewer side effects, lower pain scores, decreased mortality, earlier mobilisation of patients and reduced hospital stay.

Key words: ambulatory surgery; breast surgery; local anesthetics; nerve blocks; paravertebral; regional anesthesia.

\section{Introduction}

Ambulatory surgery often involves surgery of the extremities, thorax and abdomen ${ }^{1,2}$. Orthopaedic surgery, thoracoscopy, breast surgery, nephrolithiasis, in-

Correspondence to: Miroslav Zupcic, MD, PhD, Clinical Hospital Centre Rijeka, Clinic of Anesthesiology and Intensive Care Medicine, Kresimirova ul.42, 51000 Rijeka, Croatia

E-mail: miro_zupcic@yahoo.com guinal herniorraphies and other abdominal wall procedures are often associated with significant postoperative pain ${ }^{2,3}$. Although, neuraxial techniques are widely utilised for ambulatory surgery, they are often insufficient for providing postoperative pain therapy once the patient has been discharged from hospital ${ }^{2-4}$. Paravertebral block (PVB) is a technique where a local anaesthetic is deposited into a space found on both sides of the spine, called the paravertebral space. It is a block 
Table 1. The most relevant studies included in the review.

\begin{tabular}{|l|l|l|l|l|}
\hline Trial & $\begin{array}{l}\text { No of } \\
\text { patients }\end{array}$ & Type of surgery & Type of PVB & Type of local anesthetics \\
\hline Hanoura et al. ${ }^{13}$ & 50 & ESWL & MPVB (Th) & $0.5 \%$ bupivacaine \\
Naja et al. ${ }^{14}$ & 60 & Breast surgery & MPVB (Th) & $0.5 \%$ bupivacaine \\
Agarwal et al..$^{15}$ & 50 & Laparoscopic cholecystectomy & BSPVB (Th) & $0.25 \%$ bupivacaine \\
Hadzic et al. ${ }^{16}$ & 50 & Inguinal herniorrhaphy & MPVB (Th + L) + PS & $0.75 \%$ ropivacain \\
Naja et al. ${ }^{17}$ & 50 & Inguinal herniorrhaphy & MPVB (Th + L) + GA & 2\% lidocaine, 0.5\% bupivacaine \\
\hline
\end{tabular}

BSPVB = Bilateral single paravertebral block; ESWL = extracorporeal shock wave lithotripsy; GA= general anesthesia; MPVB - multiple paravertebral block; $\mathrm{L}=$ lumbar; $\mathrm{Th}$ = thoracic; $\mathrm{PS}=$ propofol sedation; $\mathrm{PVB}=$ paravertebral block; $\mathrm{SPVB}=$ single paravertebral block

with a dermatomal distribution of pain relief depending on the level of the spine at which the block is sited and the quantity and type of deposited local anaesthetic ${ }^{5}$.

PVB is effective for therapy of both acute and chronic pain in the thoracic, abdominal and limb regions as well as in ambulatory surgery ${ }^{6-8}$. It has been in use since the beginning of the $20^{\text {th }}$ century, when it was first described by surgeon Hugo Sellheim (18711936), for abdominal analgesia. After several decades of neglect, its application was revitalised in the 1940s with the use of paravertebral catheterisation for analgesia purposes (Eason \& Wyatt 1979) ${ }^{5,9}$. With the progress of surgery and anaesthesia, more and more surgical procedures are conducted on ambulatory, daysurgery principles ${ }^{1,3,4}$. As with other techniques of regional anaesthesia, $\mathrm{PVB}$ alone, or in combination with general anaesthesia, results in a better quality of analgesia, fewer side effects and a shorter length of hospital stay $^{10-12}$.

The aim of this narrative review is to assess the efficacy of PVB alone or in combination with general anaesthesia, in order to achieve a satisfactory perioperative analgesia in ambulatory surgery.

\section{Material and Methods}

We conducted a search of medical literature published in English, through PubMed, Google Scholar and Ovid Medline ${ }^{\circledR}$. Peer-reviewed professional articles, review articles, retrospective and prospective studies, case reports and case series, were systematically reviewed for the time period from November 2003 until February 2019. Other types of publications such as editorials and letters to editors, animal experiments, in vitro studies and studies in infants were ex- cluded. The search strategy consisted of the following Medical Subject Headings (MeSH) terms: abdominal surgery; ambulatory surgery; breast surgery; local anaesthetics; nerve blocks; orthopaedic surgery; paravertebral; regional anaesthesia; thoracic surgery. The initial screen was based on titles and abstracts of articles on PVB in ambulatory or same day surgery with adverse effects and complications. First, we had read the abstracts of 180 papers and excluded 130 irrelevant articles. We have read 50 full-text articles and excluded articles which do not meet inclusion criteria and those not mentioning PVB anaesthesia/analgesia and pain management or those articles which we found not suitable for the aim of our review.

\section{Results}

We reviewed twenty-nine articles for relevant information and a critical appraisal of the literature was performed. The most important studies included in the review were; 11 systematic reviews, 2 meta analyses, 2 retrospective and 9 randomised controlled trials (RCT). RCTs included in this review showed an efficiency of PVB application in ambulatory surgery both as a sole technique and in combination with general anaesthesia, when compared to other methods and modalities of anaesthesia and analgesia (Table 1) 13-17. $^{13}$. The failure rate associated with PVB is from $2.8-6.1$ $\%{ }^{7,12}$. Pneumothorax and pleural puncture are reported in $1 \%$ of cases, but with the additional use of ultrasound, these numbers are further reduced.

Haematoma formation is seen in $2.4 \%$ of patients and a risk of inadvertent vessel puncture is present in $5 \%$ of patients. Hypotension occurred in $4 \%$ of patients with unilateral PVB and in 9\% when bilateral PVB was applied, which can be explained by the as- 
sociated sympathetic blockade, epidural spread of local anaesthetic or the vasodilatory effect of local anaesthetics ${ }^{10,13,18}$. The incidence of complications is increased with bilateral use of PVB.

Postoperative nausea and vomiting are significantly decreased in patients with PVB application in comparison to general anaesthesia ${ }^{15,16}$.

\section{Discussion}

In this narrative review, we analysed the role of PVB in ambulatory surgery with regard to the site and type of application and to the surgical procedure performed. PVB is, according to the site of application, classified as cervical, thoracic or lumbar ${ }^{5}$.

Cervical PVB is administered between the $5^{\text {th }}$ and $7^{\text {th }}$ cervical vertebrae for anaesthesia and analgesia of the upper limb (especially in shoulder surgery, where there is a need for preservation of motor function in the arm and hand) and as a method of pain therapy with tumours that infiltrate the brachial plexus (Pancoast tumour) ${ }^{19,20}$.

Thoracic PVB (TPVB) is applied in the wedge shaped paravertebral space, found on both sides of the spinal column. The anterior and lateral border of the space is formed by the parietal pleura, while the base is formed by the posterior and lateral parts of the vertebrae, intervertebral disc and intervertebral foramina. The posterior wall is formed by the superior costotransverse ligament which is spread between two transverse processes of the vertebrae.

Laterally, from the tip of the transverse process, the paravertebral space is continued by the intercostal space. Cranially, the paravertebral space is adjacent to the adipose tissue surrounding the humeral nerve complexes, the phrenic nerve and the cervical sympathetic chain, which can result in local anaesthetic spread to these structures after block application.

The space contains adipose tissue in which the spinal nerves, intercostal vessels and sympathetic chain are lodged ${ }^{5,9}$. The caudal border is formed by the psoas major at the level of the $12^{\text {th }}$ thoracic vertebra. Therefore, local anaesthetic administration in the lower thoracic paravertebral space (thoracic 11 ) behind the internal thoracic sheath, can result in a caudal spread of local anaesthetic in the retroperitoneal space beyond the transverse fascia where the roots of the lumbar nerves can be found. This method of administering local anaesthetics most commonly results in a prolonged unilateral anaesthesia as well as a possible lumbar PVB, depending on the dose and volume of anaesthetic ${ }^{5,21}$. There are many studies stating the benefits of ambulatory breast surgery in only PVB or in combination with general anaesthesia ${ }^{10,11,14,22}$. There is also a significantly present application of PVB in day surgery of inguinal hernia repair in both children and adults, in lithotripsy, video assisted thoracic surgery, gall bladder removal and chronic pain therapy $7,9,10,13,15-18,23$. Depending on the type of surgery and expected postoperative analgesic requirement, $\mathrm{PVB}$ is applied either unilaterally, bilaterally or with a catheter insertion technique for continued postoperative analgesia ${ }^{8,10,24}$.

Unilateral application can be conducted on one or more vertebral levels, with or without catheter insertion $^{5,8,10,12,24}$. Bilateral application is most commonly a single shot technique on two levels, depending on the type of surgery, in order to avoid potential complications (local anaesthetic toxicity and haemodynamic instability $)^{5,8,10,12,25}$. Unilateral application is used in breast surgery, thoracic surgery, cardiac pacemaker insertion, rib fractures, open cholecystectomy, liver resections, oesophageal and gastric surgery, partial or complete nephrectomies, inguinal herniorraphy $5,7,8,10,12,13,15-$ 18,23. Bilateral application is used in cardiac surgery, oesophageal surgery, umbilical hernia repair, pelvic surgery, vaginal delivery, prostatectomy and hysterectomy $5,8,10,24$. Studies to date, show that bilateral PVB application in adult and paediatric surgery is not related to increased risk of systemic toxicity mediated by local anaesthetics ${ }^{26}$. Application of catheters for continued postoperative analgesia is especially recommended in surgery on the thorax with lung resection, serial rib fractures, nephrectomy and extensive breast surgery $5,8,10,19,24$.

Lumbar PVB is applied $2.5 \mathrm{~cm}$ away from the spinous process at the level of the lumbar spinal nerve roots (lumbar 1 to 4 ) with a combination of nerve stimulator and ultrasound use, such that the patient is positioned in a lateral supine position, with the nonoperative side being dependent, with the legs flexed at the hips and the patella and muscles of the upper leg visible to the eye of the operator. Indications for lumbar PVB are analgesia for hip and knee surgery, paediatric orthopaedic procedures, vaginal delivery, and femoropopliteal bypass surgery ${ }^{27,28}$. It is often compared with lumbar plexus block ${ }^{27}$. PVB is contraindicated if there are infections at the intended block application site, history of allergy to local anaesthetics, 
tumours that infiltrate the paravertebral space and patient refusal. Coagulopathy, clotting disorders or anticoagulant therapy are relative contraindications for PVB. According to the existing guidelines for regional anaesthesia, PVB represents a medium risk type of procedure for patients who are on anticoagulant or antiplatelet medication, with a defined time period between drug administration and block application ${ }^{29}$. There are two main types of techniques for PVB: landmark technique and ultrasound guided technique.

During PVB application, the positioning of the patient is very important and patients can either be positioned supine or in a sitting position. Every patient should be fully monitored in accordance to regional anaesthesia guidelines, sedated and analgised as appropriate with full resuscitation equipment available for an emergency situation ${ }^{24}$.

\section{Conclusions}

Our narrative review has shown an efficacy of PVB either alone or in combination with general anaesthesia in providing a satisfactory perioperative analgesia in ambulatory surgery.

Application of PVB is associated with better postoperative pain control during the first 24 hours after surgery, resulting in reduced opioid consumption, fewer side effects and lower pain scores when compared to general anaesthesia alone. By using a multimodal analgesic approach through a combination of PVB with other types of anaesthesia and analgesia, there is a net reduction in mortality, earlier mobilisation and reduced length of hospital stay.

\section{Acknowledgements}

This review article was funded through departmental fundings only. The authors have no conflicts of interest.

Funding / potential competing interests: No financial support and no other potential conflict of interest relevant to this article were reported.

\section{Reference}

1. Moore JG, Ross SM, Williams BA. Regional anesthesia and ambulatory surgery. Curr Opin Anaesthesiol. 2013;26:652-60. doi: 10.1097/ACO.0000000000000011.
2. Beaussier M, Sciard D, Sautet A. New modalities of pain treatment after outpatient orthopaedic surgery. Orthop Traumatol Surg Res. 2016;102:121-4. doi: 10.1016/j.otsr.2015.05.011.

3. Kopp SL, Horlocker TT. Regional anaesthesia in day-stay and short-stay surgery. Anaesthesia. 2010;65 Suppl 1:84-96. doi: 10.1111/j.1365-2044.2009.06204.x.

4. Prabhakar A, Helander E, Chopra N, Kaye AJ, Urman RD, Kaye AD. Preoperative Assessment for Ambulatory Surgery. Curr Pain Headache Rep. 2017;21:43. doi: 10.1007/s11916017-0643-7.

5. Karmakar MK. Thoracic paravertebral block. Anesthesiology. 2001;95:771-80.

6. Brown DL. Paravertebral Block.U: Boezaart AP, Galway UA, Rathmell JP, Rosenquist RW, Sites BD, Spence BC. Atlas of Regional Anesthesia. - 4 th ed. Philadelphia: Saunders, an imprint of Elsevier Inc., 2010:245 - 54.

7. El-Boghdadly K, Madjdpour C, Chin KJ. Thoracic paravertebral blocks in abdominal surgery - a systematic review of randomized controlled trials. Br J Anaesth. 2016;117:297-308. doi: 10.1093/bja/aew269.

8. Greengrass R, Buckenmaier CC 3rd. Paravertebral anaesthesia/analgesia for ambulatory surgery. Best Pract Res Clin Anaesthesiol. 2002;16:271-83.

9. Eason MJ, Wyatt R. Paravertebral thoracic block-a reappraisal. Anaesthesia.1979;34:638-42.

10. Schnabel A, Reichl SU, Kranke P, Pogatzki-Zahn EM, Zahn PK. Efficacy and safety of paravertebral blocks in breast surgery: a meta-analysis of randomized controlled trials. $\mathrm{Br} \mathrm{J}$ Anaesth. 2010;105:842-52. doi: 10.1093/bja/aeq265.

11. Parikh RP, Sharma K, Guffey R, Myckatyn TM. Preoperative Paravertebral Block Improves Postoperative Pain Control and Reduces Hospital Length of Stay in Patients Undergoing Autologous Breast Reconstruction after Mastectomy for Breast Cancer. Ann Surg Oncol. 2016;23:4262-9.

12. Naja Z, Lönnqvist PA. Somatic paravertebral nerve blockade. Incidence of failed block and complications. Anaesthesia. 2001;56:1184-8.

13. Hanoura S, Elsayed M, Eldegwy M, Elsayed A, Ewieda T, Shehab M. Paravertebral block is a proper alternative anesthesia for outpatient lithotripsy. Anesth Essays Res. 2013;7:365-70. doi: 10.4103/0259-1162.123238.

14. Naja MZ, Ziade MF, Lönnqvist PA. Nerve-stimulator guided paravertebral blockade vs. general anaesthesia for breast surgery: a prospective randomized trial. Eur J Anaesthesiol. 2003; 20:897-903.

15. Agarwal A, Batra RK, Chhabra A, Subramaniam R, Misra $\mathrm{MC}$. The evaluation of efficacy and safety of paravertebral block for perioperative analgesia in patients undergoing laparoscopic cholecystectomy. Saudi J Anaesth. 2012;6:344-9. doi: 10.4103/1658-354X.105860.

16. Hadzic A, Kerimoglu B, Loreio D, Karaca PE, Claudio RE, Yufa M, et al. Paravertebral blocks provide superior same-day recovery over general anesthesia for patients undergoing inguinal hernia repair. Anesth Analg. 2006;102:1076-81. 
17. Naja ZM, Raf M, El Rajab M, Ziade FM, Al Tannir MA, Lönnqvist PA. Nerve stimulator guided paravertebral blockade combined with sevoflurane sedation versus general anesthesia with systemic analgesia for postherniorrhaphy pain relief in children: a prospective randomized trial. Anesthesiology. 2005; 103:600-5.

18. Page EA, Taylor KL. Paravertebral block in paediatric abdominal surgery-a systematic review and meta-analysis of randomized trials. Br J Anaesth. 2017;118:159-66.doi: 10.1093/bja/ aew387.

19. Boezaart AP, De Beer JF, Nell ML. Early experience with continuous cervical paravertebral block using a stimulating catheter. Reg Anesth Pain Med.2003;28:406-13.

20. Peláez R, Pascual G, Aguilar JL, Atanassoff PG. Paravertebral cervical nerve block in a patient suffering from a Pancoast tumor. Pain Med. 2010;11:1799-802. doi: 10.1111/j.1526-4637. 2010.00994.x.

21. Lönnqvist PA, Hildingsson U. The caudal boundary of the thoracic paravertebral space. A study in human cadavers. Anaesthesia. 1992;47:1051-2.

22. Jones MR, Hadley GR, Kaye AD, Lirk P, Urman RD. Paravertebral Blocks for Same-Day Breast Surgery. Curr Pain Headache Rep. 2017;21:35.doi:10.1007/s11916-017-0637-5.

23. Mariani A, Peycelon M, Clermidi P, Bellon M, Skhiri A, Bonnard A. Safety Assessment for Thoracoscopic Day Case Surgery in Children with Congenital Pulmonary Malformation. J Laparoendosc Adv Surg Tech A. 2018;28:1129-34. doi: 10.1089/lap.2017.0721.
24. Chelly JE. Paravertebral blocks. Anesthesiol Clin. 2012;30:7590. doi: 10.1016/j.anclin.2011.12.001.

25. Župčić M, Graf Župčić S, Duzel V, Šimurina T, Šakić L, Fudurić J, et al. A combination of levobupivacaine and lidocaine for paravertebral block in breast cancer patients undergoing quadrantectomy causes greater hemodynamic oscillations than levobupivacaine alone. Croat Med J. 2017;58:270-80. doi: 10.3325/cmj.2017.58.270.

26. Richardson J, Lönnqvist PA, Naja Z. Bilateral thoracic paravertebral block: potential and practice. Br J Anaesth. 2011;106: 164-71. doi:10.1093/bja/aeq378.

27. Wardhan R, Auroux AS, Ben-David B, Chelly JE. Is L2 paravertebral block comparable to lumbar plexus block for postoperative analgesia after total hip arthroplasty? Clin Orthop Relat Res. 2014;472:1475-81. doi:10.1007/s11999-013-3393-9.

28. Gadsden J.Indications for Peripheral Nerve Blocks.In: Hadzic A, Carrera A, editors. Hadzic's peripheral nerve blocks and anatomy for ultrasound - guided regional anesthesia. $2^{\text {nd }} \mathrm{ed}$. New York: McGraw - Hill,2012.p.81-94.

29. Narouze S, Benzon HT, Provenzano DA, et al. Interventional spine and pain procedures in patients on antiplatelet and anticoagulant medications: guidelines from the American Society of Regional Anesthesia and Pain Medicine, the European Society of Regional Anaesthesia and Pain Therapy, the American Academy of Pain Medicine, the International Neuromodulation Society, the North American Neuromodulation Society, and the World Institute of Pain. Reg Anesth Pain Med. 2015;40:182-212. doi: 10.1097/AAP.0000000000000223.

\title{
ULOGA PARAVERTEBRALNIH BLOKOVA U AMBULATORNOJ KIRURGIJI: PREGLED LITERATURE
}

\author{
M. Župcicic, D. Dedic, S. Graf Župčic, V. Đuzel, T. Šimurina, L. ̌̌akic, \\ I. Grubješic, I. Šutic, I. Šutić i A. Korušić
}

Ambulatorna kirurgija uključuje kirurške zahvate na udovima, u području prsnog koša i trbuha koji su često povezani s pojavom jake perioperacijske boli. Cilj ovoga narativnog preglednog članka je preispitati učinkovitost primjene paravertebralnoga bloka (PVB) samostalno ili u kombinaciji s općom anestezijom u postizanju zadovoljavajuće perioperacijske analgezije kod ambulatorne kirurgije naspram drugih analgetskih metoda. Proveli smo istraživanje aktualne medicinske literature napisane na engleskom jeziku kroz PubMed, Google Scholar i Ovid Medline ${ }^{\circledR}$. Recenzirani stručni članci, pregledni članci, retrospektivne i prospektivne studije, prikazi slučajeva i serije slučajeva sustavno su pretraživani u razdoblju između studenog 2003. i veljače 2019. godine. Istraživanja uključena u naš narrative review prikazala su učinkovitost primjene PVB samostalno ili u kombinaciji s općom anestezijom u postizanju zadovoljavajuće perioperacijske analgezije kod ambulatorne kirurgije. Multimodalnim analgetskim pristupom primjene kombinacije PVB s drugim tehnikama anestezije i analgezije postiže se smanjenje potrošnje opioida, manje nuspojava, niže vrijednosti procjene boli na vizualno analognoj ljestvici, smanjenje mortaliteta, brža mobilizacija bolesnika te skraćenje vremena boravka u bolnici.

Ključne riječi: ambulatorna kirurgija; kirurgija dojke; lokalni anestetici; živčani blokovi; paravertebralni; regionalna anestezija. 